Original Paper http://ajol.info/index.php/ijbcs http://indexmedicus.afro.who.int

\title{
Effect of different substrates on the growth and protein content of oyster mushroom (Pleurotus florida)
}

\author{
Abiodun Olusola SALAMI*, Faith Ayobami BANKOLE et Olakunle Isaac OLAWOLE \\ Department of Crop Production and Protection, Obafemi Awolowo University, Ile Ife, Osun State, Nigeria. \\ *Corresponding author; E-mail: sola1salami@yahoo.com; Tel: +2348032348318
}

\begin{abstract}
The objectives of this study are to select the best substrate that supports the growth of mushroom and the best substrate that produces mushroom with highest protein and biological efficiency. Pure culture of Pleurotus florida were collected and cultured using white sorghum grains to produce the grain spawns which were then inoculated on pasteurized substrates in axenic condition where mushroom emerged. Four substrates were composted in the investigation of the effect of substrates variability on the growth and protein content of oyster mushroom. Data relating to the time taken for spawn ramification, pinhead formation, days to maturity of the fruiting bodies as well as the protein content of the mushroom were collected. All the substrates were colonised at the same rate but pin head formation was first noticed on sugarcane bagasse substrate followed by maize straw substrate but with the fastest maturity of the fruiting bodies. Mushroom from sugarcane bagasse substrate had the highest yield while the lowest yield was observed on banana leaves followed oil palm spadix substrates. Mushroom from maize straw had the highest protein content $(48.79 \%)$ while the lowest was from oil palm spadix substrate $(23.41 \%)$.

(c) 2016 International Formulae Group. All rights reserved.
\end{abstract}

Keywords: Substrate variability, growth, protein content, oyster mushroom.

\section{INTRODUCTION}

Mushroom is fleshy, spore-producing fruiting bodies of some higher fungi. Mushrooms are saprophytes and they include members of the Basidiomycota and some members of the Ascomycota (Jebapriya et al., 2013). They consist of two main parts, the mycelium and the fruity body (sporocarp). The mycelium consists of a treelike structure called hyphae hidden in the soil. The mycelium absorbs food nutrients while the hyphae form into mycelia which forms the fruit (sporocarp) structure on the surface when atmospheric conditions particularly humidity is favourable (Oei, 2003). They are produced above ground on soil (hypogenous). Unfortunately, mushrooms are very delicate, they do not last, some have a life span of less than a day others may survive one week, and a group of tougher mushrooms may last months but they have a tough woody texture (Oei, 2003). Mushroom consumption dates back to years before the birth of Christ (Markson et al., 2012). Over the years, mushrooms have been collected and consumed as part of the daily meals in many parts of the world (Kumari et al., 2008). Mushroom domestication began in France in 1707 with 
the cultivation of the white button mushroom (Agaricus bisporus) and at the end of the 19th century, multi-spore techniques for mushroom production was also developed in France (Aaronson, 2000). Mushroom which is a fleshy saprophyte fungus are found growing on damp rotten log of wood trunk of trees, decaying organic matter and in damp soil rich in organic substances. Edible mushroom are highly nutritious and can be compared with eggs, milk and meat (Oei, 2003). Moore and Chi (2005) confirmed that edible mushrooms have high nutritional attributes and potential applications in industries. Oyster (Pleurotus) mushrooms are considered to be one of the most efficient producers of food protein, producing $30 \%$ of its dry weight (Chi, 2005). Therefore, mushrooms can be a good supplement to cereals (Oei, 2003; Okoro, 2012). Protein content of mushroom varies from $4-44 \%$ according to the species (Oei, 2003), whereas, the other foods like beef and wheat contain protein of about 16 and $1 \%$ respectively. They also contain folic acid, which is blood building vitamin and counteracts anaemia. Oyster mushroom is one of the most versatile mushrooms which is an excellent source of vitamin B1 (thiamine), B2 (riboflavin), B3 (nicotinic acid), C (ascorbic acid) and biotin (Shah et al., 2004; Grace, 2015). It has been estimated that the number of mushrooms on earth is about 140,000 yet only $14,000(10 \%)$ are known (Hawksworth, 2001). One of the values of commercial cultivation of mushrooms, especially in a developing economy like Nigeria, is the availability of large quantities of several agroindustrial wastes which can serve as substrate for the cultivation of mushrooms (Banjo et al., 2004; Chiejina, 2015). A substrate is any substance that can facilitate mycelia growth. Mushroom is not grown directly on soil as other crops but on organic substrate either raw or composted. These substrates are mostly materials from farm, plantations or factories. Throughout the Eastern and Southern African regions, mushrooms have become a popular vegetable due to its protein and vitamin content as well as culinary appeal. Edible mushroom are highly nutritious and can be compared with eggs, milk and meat (Oei, 2003). The content of essential amino acids in mushroom is high and close to the need of the human body. Mushroom is easily digestible and it has no cholesterol content. However, the cultivation of mushroom is still very limited and the industry is still at its infancy in Nigeria (Belewu, 2002; Belewu, 2003). The nutritional value of food is primarily determined by their protein content and reserve of carbohydrates (or fats). High concentrations of carbohydrate and nitrogen sources are usually needed in order to achieve a high yield (dry weight) of mycelium. But too high a concentration of glucose can have an inhibitory growth effect on several mushrooms. During an investigation of the cultivation of mushroom on agricultural residues, it was found that rice husk sorghum stover, saw dust, cotton waste, cocoa bean shell, and sawdust - Gliricidia mixture are suitable substrates for the cultivation of edible mushroom (Belewu, 2001; Belewu and Ademilola, 2002; Belewu, 2003; Belewu and Lawal, 2003), while, rice straw, water lilly and banana leaves are equally implicated (Oei, 2003). It was also recorded that mushroom can grow on chopped cocoa pods, cotton waste, dried chopped maize straw, sugarcane bagasse, newsprint, old rags and sawdust (Banjo et al., 2004). Cereal straw used for cultivation of oyster mushroom is a poor source of nitrogen $(0.5$ to $0.8 \%)$ and at the time of fructification when most of the nitrogen is utilized for mycelial growth, the depleted nitrogen in the substrate becomes inadequate and limits mushroom yield (Upadhyay et al., 2002). Efficiency of protein production and flavour formation vary with different carbon and Nitrogen sources. Protein content of the mushroom mycelium can be controlled by the amount of nitrogen supplied in the growth media. The range of carbon: nitrogen $(\mathrm{C}: \mathrm{N})$ ratio is important. This also influences the yield and efficiency of the production of mushroom mycelium. Environmental factors such as temperature, oxygen, carbon(iv)oxide, humidity, light, 
moisture and $\mathrm{pH}$ have been reported to also affect mycelia growth in the spawn preparation (Nwanze et al., 2005). Also, the most common bacterial problem in Pleurotus cultivation is infection by Pseudomonas tolaasi (Royce, 2003). Over 30 species of fungi cause severe crop loss. The nutritional value of food is primarily determined by their protein content and reserve of carbohydrates (or fats). The nutritional quality of feed ingredient is dependent on its chemical constituents which carries a nutritional significance. The objectives of this study are to select the best substrate that supported the growth of mushroom, determine the protein content of mushroom with varying substrate, determine the element(s) present in the substrate that accounts for the nutrient content of the mushroom and select the best substrate that produces mushroom with highest protein and biological efficiency.

\section{MATERIALS AND METHODS}

\section{Scope of the study}

The research was carried out in the mycology laboratory of the Department of Crop Production and Protection. The substrates used include; Dry banana leaves, Sugarcane bagasse, Maize straw, and Oil palm spadix. Spawns of Oyster mushroom (Pleurotus florida) was collected from the Mycology laboratory of the Department of Crop Production and Protection, Obafemi Awolowo University, Ile-Ife, and grown on four (4) different substrates (named above) with three (3) replications which will give a total of 12 plastic plates of cultivated mushroom.

\section{Production of spawn}

Spawn of the mushroom was produced using sorghum grains. The grains were washed and parboiled for about 30 minutes after which it was decanted and allowed to cool. Calcium carbonate was added to regulate the $\mathrm{pH}$ of the grains. Labelled, sterilized jam bottles were filled with these grains up to about $3 / 4$ of the size of the bottle. The bottles were corked with cotton wool and aluminium foil paper and later autoclaved at $121{ }^{\circ} \mathrm{C}$ for 20 minutes after which the bottles were allowed to cool at room temperature. A little of the grain spawn was dropped in these labelled bottles and allowed to incubate for about 1-2 weeks for full colonization.

\section{Preparation of substrate}

Maize straw, sugarcane bagasse and their additives were steamed with hot water. The banana leaves was shredded into bits of about $2 \mathrm{~cm}$ and soaked in hot water. The oil palm spadix was soaked with Calcium carbonate $\left(\mathrm{CaCO}_{3}\right)$. Calcium carbonate was used to neutralize the acidity of the spadix. The substrates were mixed with calcium carbonate to adjust the $\mathrm{pH}$ to a range (5-9) for optimum mycelia colonization. The substrates were then packed into transparent plastic plates.

\section{Inoculation of the substrate}

Each plate was inoculated with a measure of the mushroom spawn. Bagging was done in an axenic condition. Transparent plastic plates were used. These plates were taken to the germination chamber until full colonization of the substrates was attained.

\section{Growth parameters}

The following parameters were noted as growth occurs.

Total number of fruiting bodies: This was done by counting the number of fruiting bodies on each substrate, Fresh weight of fruiting bodies after harvesting: This was weighed using an electronic weighing balance, Dry weight of fruiting bodies, this was weighed using a weighing balance after oven drying at $80^{\circ} \mathrm{C}$ for 15 minutes, Date of appearance of the fruiting body (the pin head) of the different species, Days of maturity.

Average growth rate was calculated by the formula;

Average Growth rate $($ mycelium $)=\frac{\mathrm{A}+\mathrm{B}}{2}$

Where $\mathrm{A}=$ shortest growth length 


$$
\mathrm{B}=\text { longest growth length }
$$

The biological efficiency was calculated using;

$$
\text { Biological efficiency } \quad=\frac{w \times 100}{W \times 1}
$$

Where $\mathrm{w}=$ Total weight of fruit bodies

$$
\mathrm{W}=\text { Total weight of substrate of }
$$
spawning

\section{Protein analysis}

The protein content of the mushroom was analysed according to the Association of Official Analytical Chemists (A.O.A.C., 2000), while the $\mathrm{pH}$ of samples was read using a $\mathrm{pH}$ meter.

\section{Nutrient composition of the substrate}

Nutrient composition analyses of the substrates were carried out. Determination of nitrogen content was done using Kjeldahl method; Potassium (K) was determined by flame photometric methods. Phosphorus content of the substrates was obtained by spectrophotometric methods (A.O.A.C., 2000), carbon content was also determined. The $\mathrm{pH}$ level of the substrates was obtained using $\mathrm{pH}$ meter. About $10 \mathrm{~g}$ each of the substrates will be crushed and dispersed in 10 $\mathrm{ml}(\mathrm{wt} / \mathrm{v})$ of distilled water separately and the test will be performed on the substrates (Oei, 2003).

\section{Statistical analysis}

The data collected were subjected to analysis of variance at 0.05 level of significance using the statistical analysis software (SAS 9.1). Microsoft excel 2007 was also used to plot the graphs.

\section{RESULTS}

All the substrates used for this investigation supported the growth of the mushroom although at different level (Plate 2). Complete colonization of the substrate took seven days though there was no significant difference among the substrates used in the experiment. The pin heads began to emerge between 11-30 days after inoculation. It was noticed first on the sugarcane bagasse substrate, maize straw substrate, and then banana leaves substrate while it took oil palm spadix substrate 30 days for pin head formation. The fruiting bodies got matured 4-5 days after the pin head formation. Average growth length was calculated by adding the shortest growth rate and the highest growth rate divided by two which gave an average of 24.5 days (Figure 1). The result from Table 1 revealed that treatment does not have significant effect on the number of fruiting body per flush i.e they were not different, while treatment was significantly different for days to pin head formation, days to fruit maturity, flush number and total flush at $0.001,0.01$, and 0.05 , levels of significance respectively. The fresh weight of the mushroom was taken and mushrooms from sugarcane bagasse substrate had the highest weight (14.02 g) which was significantly different from that of oil palm spadix substrate and banana leaves substrate but not significantly different from maize straw substrate (Table 2). The total flush from sugarcane bagasse substrate was significantly different from that of oil palm spadix substrate $(7.616 \mathrm{~g})$ and banana leaves substrate $(6.98 \mathrm{~g})$ but not different from maize straw substrate $(10.38 \mathrm{~g})$ (Figure 2). Figure 3 shows the biological efficiency of each substrate (where the weight of the substrates was worked against the average yield of the mushroom). Following the composition analysis carried out on the substrates, Nitrogen, phosphorus, Potassium and carbon were determined (Table 4). The protein analysis of the fruiting bodies from each substrates used was determined using the A.O.A.C. (2002) method. The result presented in Table 5 and Figure 4. Mushroom from maize straw had the highest protein content which was significantly different from other substrates while mushroom from Banana leaves had the lowest protein content. 
A.O. SALAMI et al. / Int. J. Biol. Chem. Sci. 10(2): 475-485, 2016

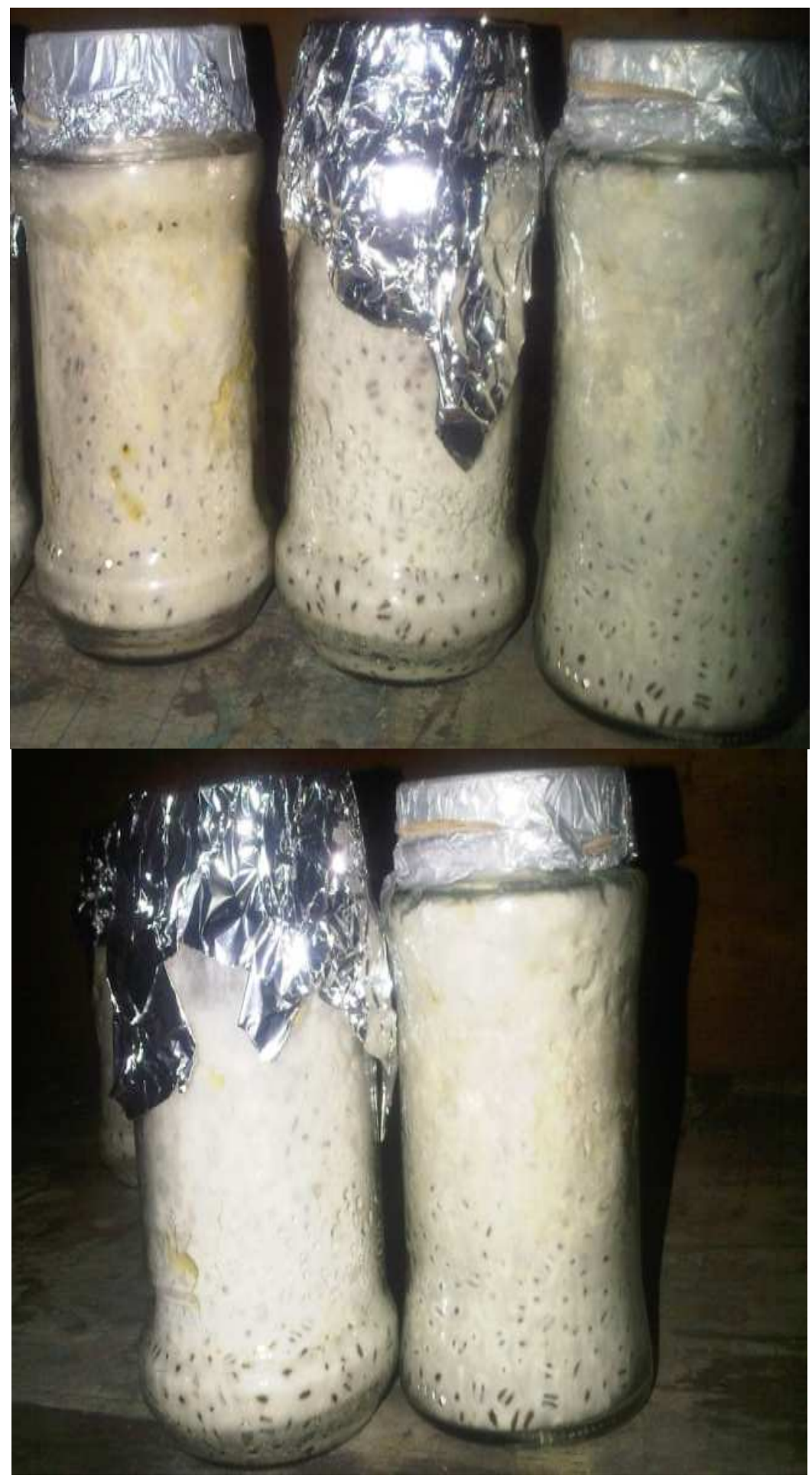

Plate 1: Grain spawns of the mushroom after complete colonization. 


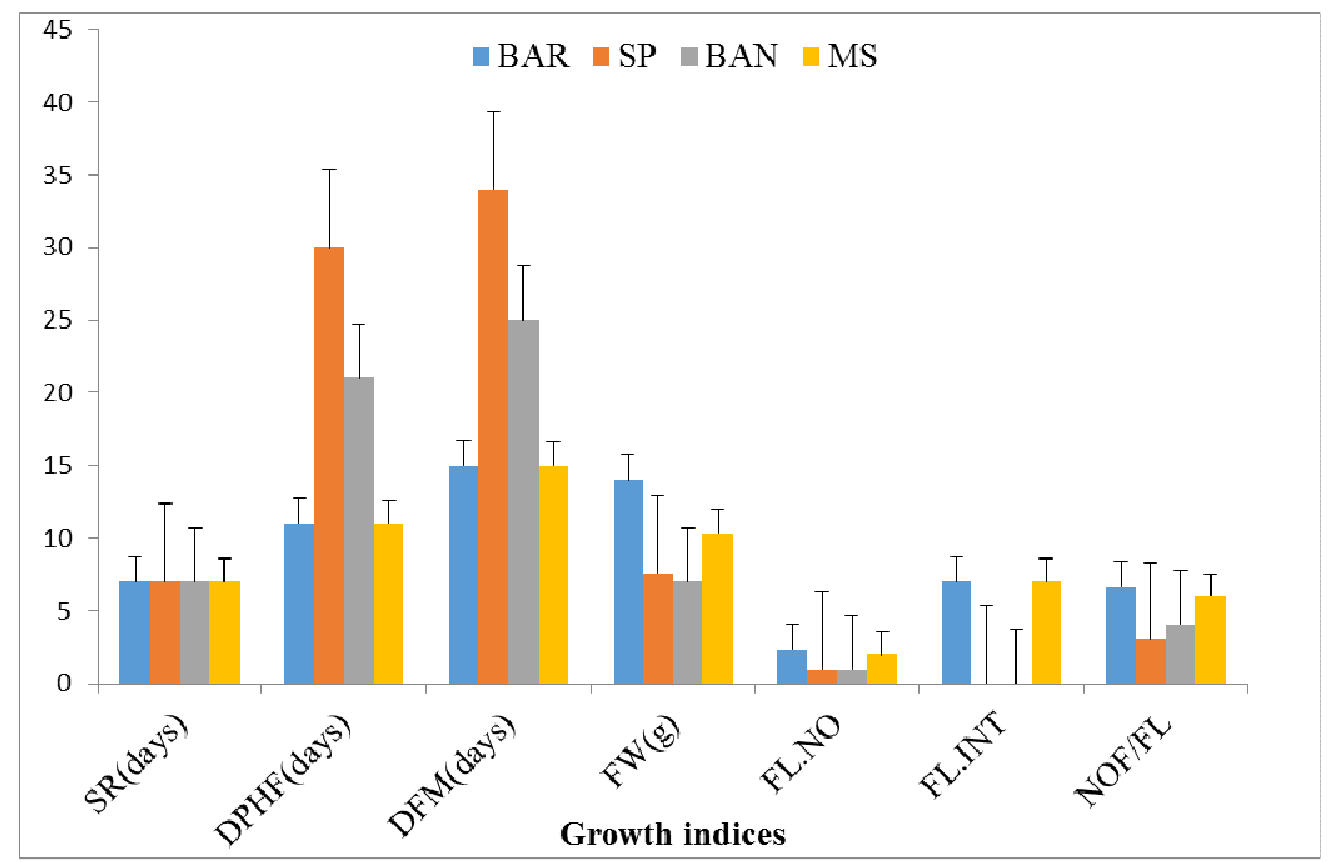

Figure 1: The indices of mushroom yield and the average of growth parameters of $P$. florida. $\mathrm{SR}=$ Spawn running, $\mathrm{DPHF}=$ Days to Pin head formation, $\mathrm{DFM}=$ Days to Fruit maturity, FW= Fresh weight, FL.NO= flush number, FL.INT= Flush interval, NOF/FL=Number of fruit per flush, TF= total flush.

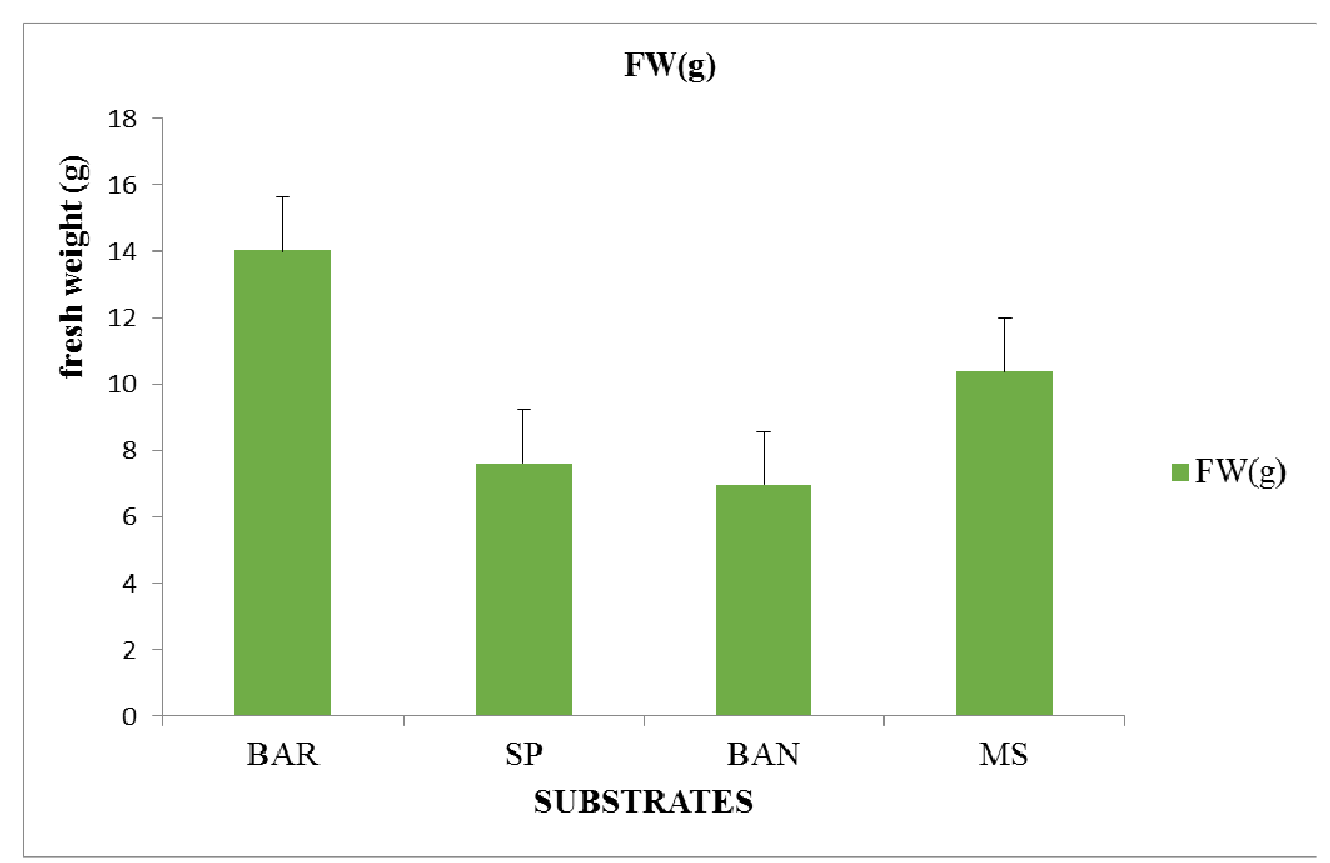

Figure 2: Fresh weight of mushroom (\%).

$\mathrm{BAR}=$ Sugarcane bagasse, $\mathrm{SP}=$ Oilpalmspadix, $\mathrm{BAN}=$ Banana leaves, $\mathrm{MS}=$ Maize straw 


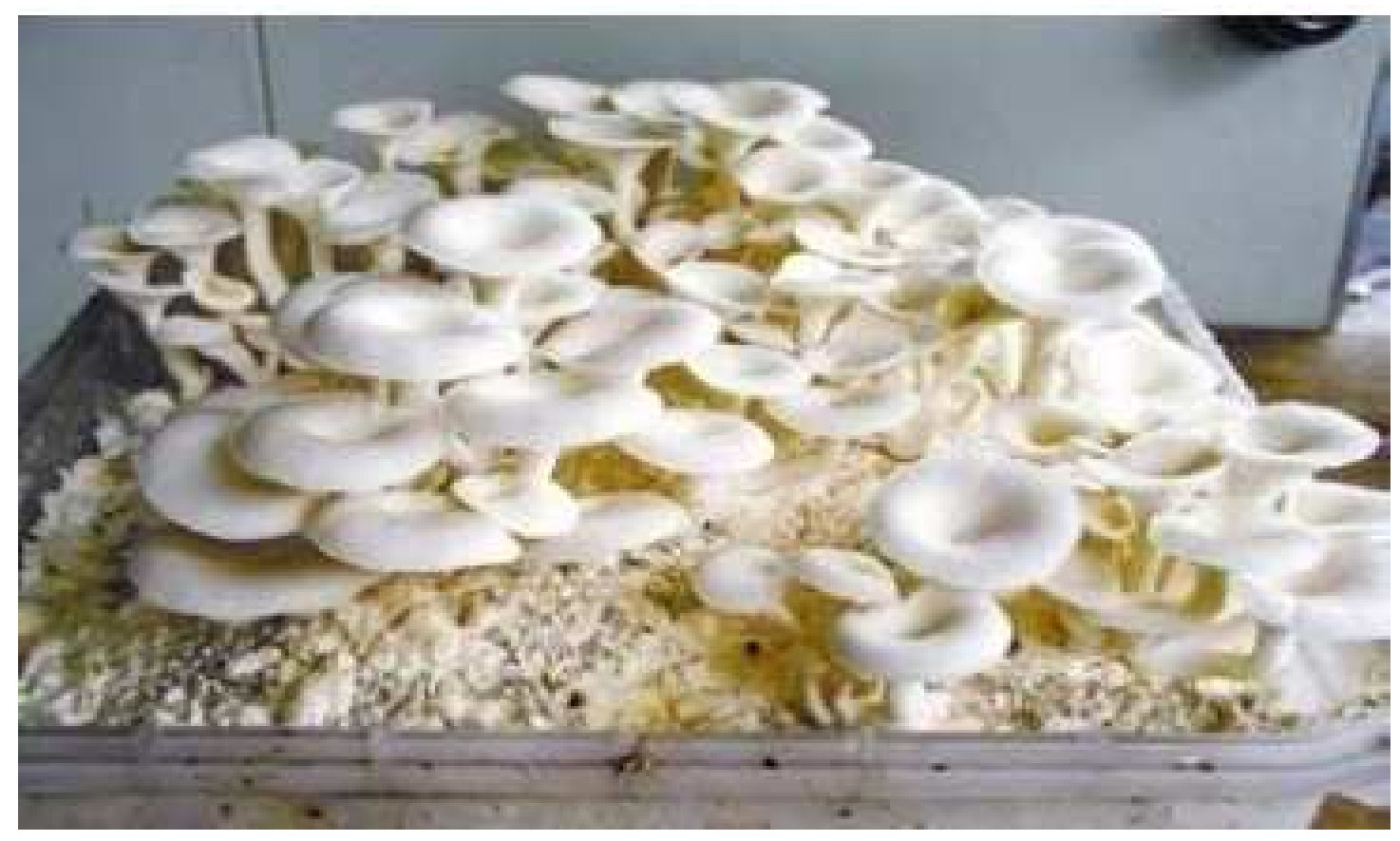

Plate 2: Mushroom at maturity.

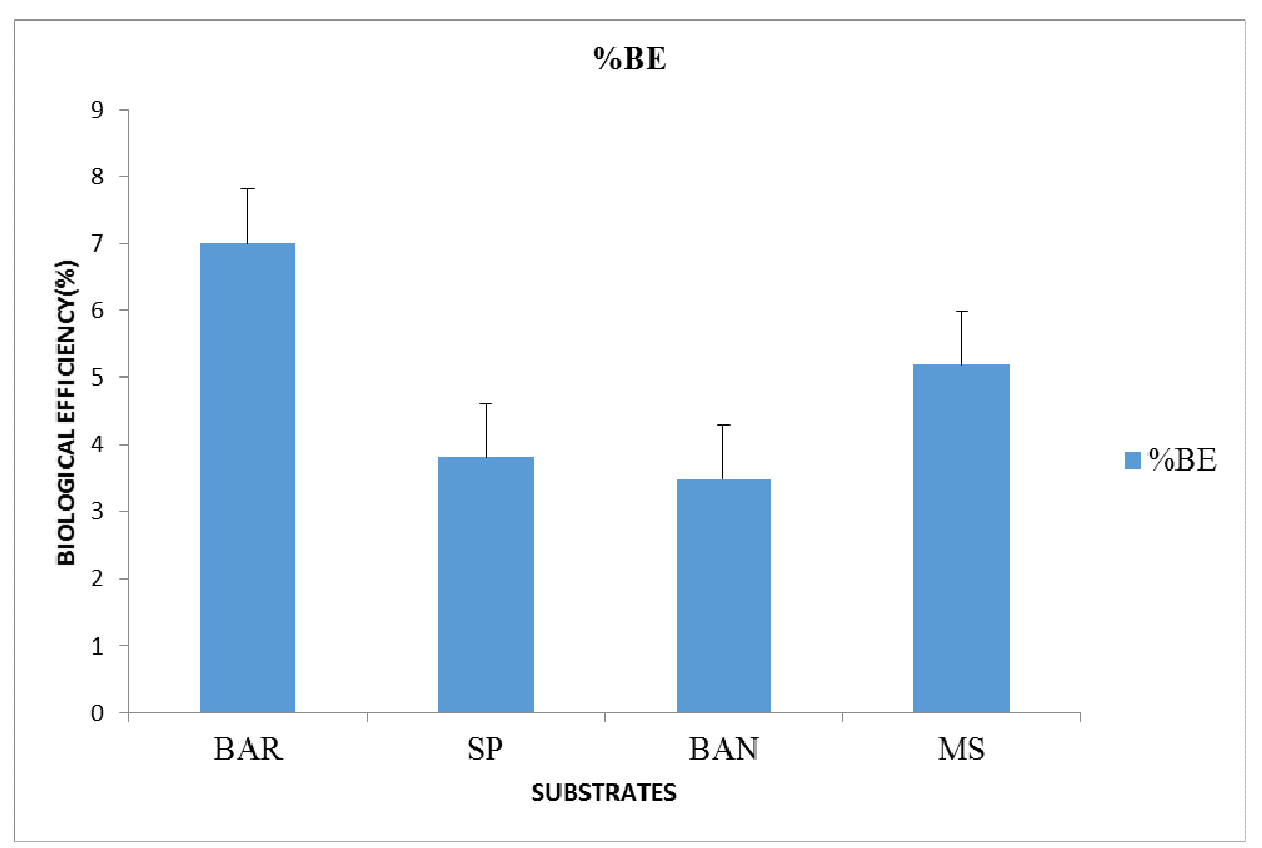

Figure 3: The Biological Efficiency of mushroom. 


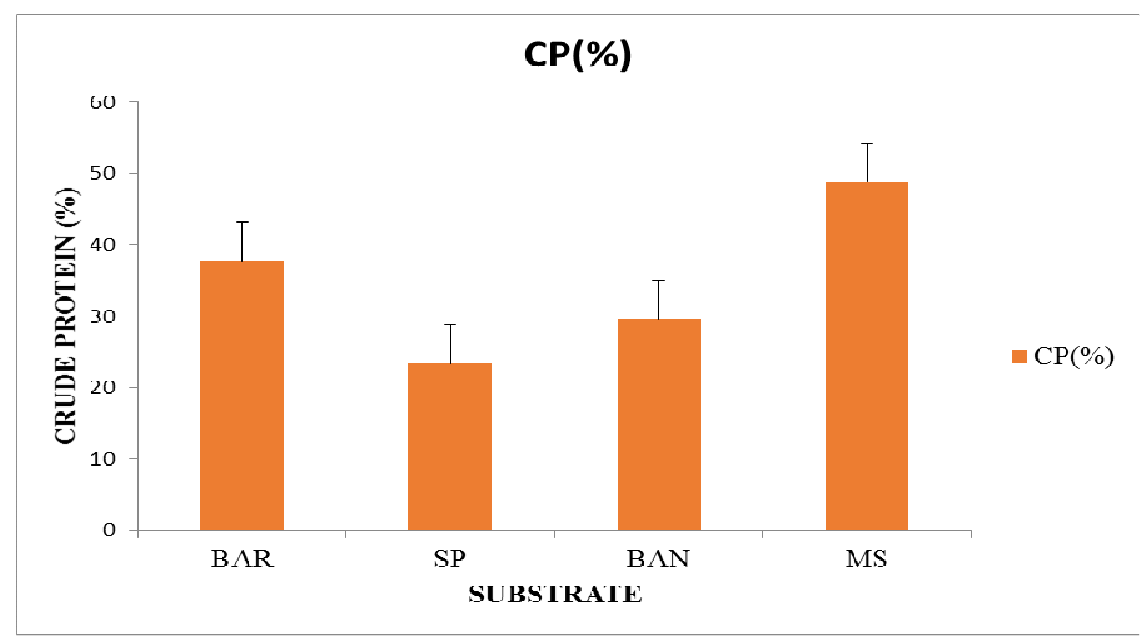

Figure 4: The percentage crude protein of the mushroom from each substrate.

Table 1: Mean square value of the average growth parameters.

\begin{tabular}{lcccccc}
\hline SOURCE & DF & DPHF & DFM & FL.NO & NOF/FL & TF \\
\hline TRT & 3 & $250.2^{* * *}$ & $250.75^{* * *}$ & $1.417^{* *}$ & $8.75 \mathrm{~ns}$ & $123.67^{*}$ \\
REP & 2 & 0 & 0 & 0.083 & 2.58 & 27.58 \\
ERROR & 6 & 0 & 0 & 0.083 & 1.92 & 24.92 \\
MEAN & & 18.5 & 22.25 & 1.583 & 4.92 & 8.833 \\
CV & & 0 & 0 & 18.2 & 28.2 & 56.5 \\
$\mathrm{R}^{2}(\%)$ & & 100 & 100 & 89.8 & 73.20 & 74.03 \\
\hline
\end{tabular}

*,**,***are significant at $0.05,0.01$, and 0.001 probability levels respectively; DPHF= Days to Pin head formation, $\mathrm{DFM}=$ Days to Fruit maturity, FL.NO= flush number; FL.INT= Flush interval, NOF/FL=Number of fruit per flush, $\mathrm{TF}=$ total flush,ns=not significant.

Table 2: Fresh weight from the substrates

\begin{tabular}{lc}
\hline Substrate & Fresh weight \\
\hline Bagasse & 14.02 \\
Spadix & 7.616 \\
Banana leaves & 6.98 \\
Maize straw & 10.38 \\
\hline
\end{tabular}

Table 3: Biological efficiency of the substrates.

\begin{tabular}{lcc}
\hline Substrates & Weight of substrates & Biological efficiency (\%) \\
\hline Bagasse & 200 & 7.01 \\
Spadix & 200 & 3.808 \\
Banana leaves & 200 & 3.49 \\
Maize straw & 200 & 5.19 \\
\hline
\end{tabular}


Table 4: Elemental composition of the substrates.

\begin{tabular}{lcccc}
\hline Substrates & $\begin{array}{c}\text { Total nitrogen } \\
(\boldsymbol{\%})\end{array}$ & Phosphorus (PPM) & $\begin{array}{c}\text { Potassium } \\
(\mathbf{C M o l} / \mathbf{K g})\end{array}$ & Carbon (\%) \\
\hline Bagasse & 0.63 & $1,704.45$ & 5.25 & 30 \\
Spadix & 0.63 & 1731.81 & 14.25 & 39 \\
Banana leaves & 0.63 & 1804.73 & 14.25 & 45.6 \\
Maize Straw & 0.56 & 1713.58 & 11.25 & 58 \\
\hline
\end{tabular}

Table 5: Crude protein content of the mushroom from the different substrates.

\begin{tabular}{lc}
\hline Substrates & Crude protein $(\%)$ \\
\hline Bagasse & 37.65 \\
Spadix & 23.41 \\
Banana leaves & 29.62 \\
Maize straw & 48.79 \\
\hline
\end{tabular}

\section{DISCUSSION}

Sorghum grains were effective in the production of mushroom spawns as the full colonization of the spawns was recorded two weeks after inoculation (Plate 1). This is as due to the carbon rich nature of cereals most especially sorghum. All the substrates used for this investigation supported the growth of the mushroom although at different levels been rich in fibre which is easily degraded by fungi (Plate 2) similar to (Banjo et al., 2004). Complete colonization of the substrate took seven days though there was no significant difference among the substrates used in the experiment. This is expected since the nature of the substrates varies across the substrates used. The result from Table 1 revealed that treatment does not have significant effect on the number of fruiting body per flush i.e they were not different, while treatment was significant different for Days to pin head formation, days to fruit maturity, flush number and total flush at $0.001,0.01$, and 0.05 , levels of significance respectively. The fresh weight of the mushroom was taken and mushrooms from sugarcane bagasse substrate had the highest weight which was significantly different from that of oil palm spadix substrate and banana leaves substrate but not significantly different from maize straw substrate (Table 2). The total flush from sugarcane bagasse substrate was significantly different from that of oil palm spadix substrate and banana leaves substrate but not different from maize straw substrate (Figure 2). Figure 3 shows the biological efficiency of each substrate (where the weight of the substrates was worked against the average yield of the mushroom). It has been established that cereal straw used for cultivation of oyster mushroom is a poor source of nitrogen $(0.5$ to $0.8 \%)$ and at the time of fructification when most of the nitrogen is utilized for mycelial growth, the nitrogen in the substrate becomes inadequate and limits mushroom yield thereby affecting the growth of the mushroom (Upadhyay et al., 2002; Abdurrahman, 2008). Following the composition analysis carried out on the substrates, Nitrogen, phosphorus, Potassium and carbon were determined. The Carbon: Nitrogen ratio of maize straw and sugarcane bagasse substrate was the highest, accounting for the good growth observed from the substrates (Table 4) which was similar to (Sławińska and Kalbarczyk, 2011). Nitrogen content of the substrate was not significantly different from each other but the carbon content was significantly different from each other. The protein analysis of the fruiting bodies from each substrates used was determined using the A.O.A.C. (2002) method. The result presented in Table 5 and Figure 4. From this analysis, Mushroom from maize straw had the highest protein content 
which was significantly different from other substrates while mushroom from Banana leaves had the lowest protein content. Protein content of the mushroom mycelium can be controlled by the amount of Nitrogen supplied in the growth media. The Carbon: Nitrogen influences the protein and the fat content in the mushroom mycelium (Shah et al., 2004). This result also corroborates the result of (Belewu, 2003) which reported that Oyster (Pleurotus) mushrooms are considered to be one of the most efficient producers of food protein, producing $30 \%$ of its dry weight. Carbon is readily available from cellulose, hemicelluloses and lignin from straw, but nitrogen occurs mainly in a bound form and is not available until it is enzymatically released (Upadhyay et al., 2002). Though the Nitrogen content in the substrates was generally low, mushroom grown on maize straw was able to efficiently convert the Nitrogen to Protein.

\section{Conclusion}

It can be concluded from the experiment, that sugarcane bagasse substrate and Maize straw substrate supported the growth of mushroom better than oil palm spadix substrate and banana leaves substrate while bagasse substrate was the best substrate. Also, the highest biological efficiency was gotten from sugar cane bagasse substrate while the mushroom grown on maize straw substrate had the highest protein content. Finally, it was observed that carbon and Nitrogen were elements responsible for the growth while Nitrogen was essential in the protein content of the mushroom. This research recommends that conservative agriculture should be enhanced and supported in that nothing within the cycle of agricultural production should be wasted. Maize straw can be used extensively in the cultivation of mushroom with high protein content which can be a substitute for expensive fish and meat which is mostly unaffordable by most as a result of poverty. Also, the technology of mushroom production must be transferred from our laboratories and colleges to the outside world where people can be educated on how to produce mushroom in homes because one of the limitation that mushroom cultivation have been facing is the lack of cultivation technology.

\section{COMPETING INTERESTS}

There are no competing interests.

\section{AUTHORS' CONTRIBUTIONS}

AOS supervised the project in the mycology laboratory of the department of Crop Production and Protection. FAB carried out the research in the laboratory and also got a faculty prize for the project and OIO assisted in the project.

\section{ACKNOWLEDGEMENTS}

Acknowledgements are due to the members of the mycology laboratory of the Department of Crop Production and Protection, Obafemi Awolowo University.

\section{REFERENCES}

Abdurrahman D, Hilal A, Abdunnasir Y. 2008. Yield performances and nutritional contents of three oyster mushroom species cultivated on wheat stalk. African Journal of Biotechnology, 7(19): 3497-3501.

Akpaja EO, Isikhuemhen OS, Okhuoya JA. 2003. Ethnomycology and usage of edible and medicinal mushrooms among the Igbo people of Nigeria. International Journal of Medicinal Mushroom, 5: 313 - 319.

Association of Analytical Chemists. 2000 Official Methods of Analysis. Association of Analytical Chemists: Washington D.C.; 21-116.

Banjo NO, Abikoye ET, Kukoye AO. 2004. Comparison of three nutrient supplements used as additives to saw dust during the cultivation of Oyster mushroom (Pleurotus pulmonaris). Niger. J. Microbiology, 18: 335-336.

Belewu MA. 2001. Effect of fungus (Volvariella volvacea) treated cotton waste as a replacement for cotton seed cake and meal by WAD goat. Trop. J. Anim. Sci., 4: 93-98. 
Belewu MA. Ademilola. 2002. Digestibility response of WAD goats to mushroom (Volvariella volvacea) treated cotton waste. Moor J. Agric. Res. 3, 83-86.

Belewu MA 2003. Nutritional qualities of corn cobs and waste paper incubated with edible mushroom (Pleurotus sajor-caju). Nig. J. Anim. Prod., 30: 20-25.

Chiejina, Nneka V, Osibe, Dandy A. 2015. Oil palm fruit fibre promotes the yield and quality of Lentinus squarrosulus (Mont.). Singer, an Edible Nigerian Mushroom, 14(14): 1195-1200.

Grace AM, Muoma J, Mwanzia B, Dorington O. 2015. Antioxidant properties of cultivated edible mushroom (Agaricus bisporus) in Kenya. African Journal of Biotechnology, 14(16): 1401-1406.

Hawksworth DL. 2001. The magnitude of fungal diversity: The 1.5 million species estimate revisited. Mycological Research, 105: 1422-1432.

Kumari D, Achal V. 2008. Effect of different substrates on the production and nonenzymatic antioxidant activity of Pleurotus ostreatus. Life Science Journal, 5(3): 1-5.

Markson, Aniedi-Abasi A, Madunagu, Bene, Bassey, Glory. 2012: Assessment of growth support potentials of different substrates for the cultivation of Volvoriella volvaceae. Journal of Biology, Agriculture and Healthcare, 2: 52-58.

Moore D, Chi SW. 2005. Fungi Products as Food pointing SB, Hyde KO (eds). In Bio-Explotation of filamentous fungi. Fungi Diversity Res. Lenis, 6: 223-251.

Nwanze PI, Khan AU, Ameh JB, Umoh VJ. 2005. The effect of the interaction of various spawn grains with the different culture medium on carpophores dry weights and stipe and pileus diameters on Lentinus squarrosullus (Mon.) singer. Afr. J. Biotechnol., 4: 615-619.

Oei p. 2003 Mushroom Cultivation: Appropriate Technology for Mushroom Growers. The Netherlands Backhuys Publishing: Leiden.

Okoro IO, Achuba FI. 2012. Proximate and mineral analysis of some wild edible mushrooms. African Journal of Biotechnology, 11(30): 7720-7724.

Royce DJ. 2003 Influence of spawn rate and commercial delayed release nutrient levels on Pleurotus cornucopiae (Oyster mushroom) yield, size and time to production, Apppl. Microbiol. Biotechnol., 58: 527-531.

Shah ZA, Ashraf M, Ishtiaq M. 2004. Comparative Study on Cultivation and Yield Performance of Oyster Mushroom (Pleurotus ostreatus) on Different Substrates (Wheat Straw, Leaves, Saw Dust). Pakistan Journal of Nutrition, 3(3): 158-160.

Sławińska A, Kalbarczyk J. 2011. Evaluation of Enzymatic Activity of Pleurotus ostreatus. Regarding Stages of Mycelium Development. Acta Sci. Pol., Hortorum Cultus, 10(2): 195-202.

Upadhyay RC, Verma RN, Singh SK, Yadav MC. Effect of Organic Nitrogen Supplementation in Pleurotus Species. National Research Centre for Mushroom: Chambaghat, Solan, India; 225-231. 